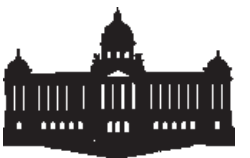

Časopis Národního muzea. Ǩada historická Journal of the National Museum (Prague). Series Historia $188 \cdot 3-4 \cdot 2019 \bullet$ (p. 91-92)

\title{
Badatel české historie
}

Před čtyřiceti léty - necelý měsíc před dosažením sedmdesátky - zamřel v Praze katolický křest’anský intelektuál a spisovatel JUDr. Václav Ryneš.

V knihách, studiích, v odborných textech a v článcích - jejichž počet jde do stovek originálním způsobem věnoval pozornost českým dějinám, zvláště národním a církevním, které tvořily vlastní těžiště jeho tvưrčí práce.

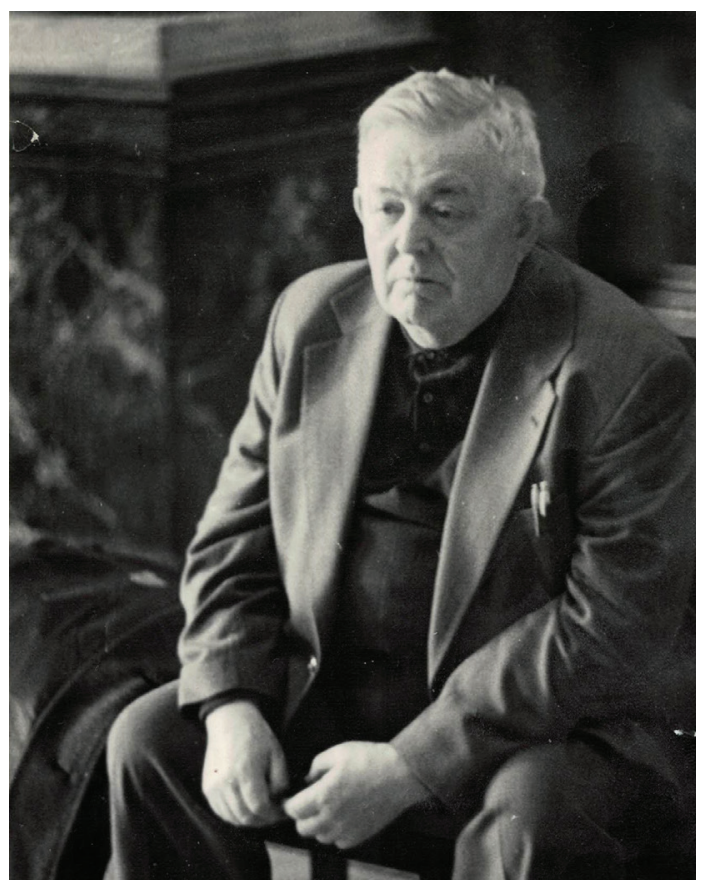

Osobnost Václava Ryneše ovlivnila kulturní a společenské dění českého předválečného a poválečného katolicismu. Po roce 1990 byl rehabilitován i politicky v rámci Československé strany lidové.

Jeho rozsáhlá tvorba výrazně literární a historická, ale i v historii umění, numismatice a heraldice, zahrnovala období padesáti let - od třicátých let až do osmdesátých let minulého století. Václav Ryneš byl právník, historik, ikonograf a předválečný předseda Sdružení katolické mládeže (SKM) a v poválečném období se angažoval v lidovecké Mladé generaci, byl pracovníkem Zemského národního výboru, ministerstva vnitra, pomocným dělníkem, vědeckým pracovníkem a odborným pracovníkem Uměleckého a průmyslového muzea a Národní galerie v Praze. Publikoval v revue Řád, v časopisech Obzory, Vývoj, Katolické noviny, Lidová demokracie a v řadě dalších novin a odborných časopisů.

Je autorem knih: Vyhnanství Bohuslava Balbína, Mlada Přemyslovna, Paládium země české, Čtení o svatém Oenestinovi, spoluautor publikace Svatý Jan Nepomucký, Atributy světců I. a II. díl, spoluautor knihy Metropolitní chrám svatého Víta a Tisíc let pražského arcibiskupství 973-1973. Václav Ryneš byl vynikající znalec české středověké a barokní historie a literatury, církevních a uměleckých výtvarných dějin. V české moderní ikonografii a hagiografii má zakladatelský význam a uplatnil se i na mezinárodním fóru statěmi 
o národních světcích (Bibliotheca Sarvatorum a další). Jeho studie: Radim - Geudencius, České knížecí pověsti, Lidická tragedie a její oběti a další byly průzkumnými pramennými pracemi.

V nepřehledném množství článků a odborných statí věnoval zvláštní pozornost české státnosti od dějinných počátků až do 20. století. V numismatice jej zaujala svatováclavská a svatovojtěšská problematika, kterou řešil novým metodickým výkladem mincovní ikonografie. Objevitelsky historické práce jsou spojeny se studiemi: Z osudu českého lva na mincích nové doby, Dočasný zánik českého státu v zrcadlech národní heraldiky 1804-1918. V jiných studiích se věnoval církevním poměrům v předhusitském období, studiu patrocinií, přispěl k dataci zařazení mnoha gotických svatyní, upozornil na farářské relace a aktivizoval opomíjené historické prameny, jako soupisy starých chrámových pokladů nebo seznamy umělců a uměleckých restaurátorů. V rámci uměleckých historických studií věnoval pozornost náboženským motivům v českém výtvarném umění a jeho rozsáhlá činnost obsahuje i řadu národopisných studií. Ve svých četných vystoupeních, projevech a přednáškách vždy udivoval rozsáhlými znalostmi a odborností. Řada jeho studií byla publikována v zahraničí v němčině, latině, italštině a španělštině. Václav Ryneš měl velmi úzké kontakty na církevní představitele první, druhé a třetí republiky a patřil do poradního kruhu pana kardinála Josefa Berana a pana kardinála Františka Tomáška. V roce 1950 byl zařazen do akce 75 tisíc a nasazen do fabriky ČKD, kde byl zaměstnán v letech 1951-1961 jako pomocný dělník a kde organizoval katolickou skupinu věřících. Celé desetiletí mu nebylo umožněno opustit dělnickou profesi. V letech 1967-1971 se aktivně zapojil do církevní obnovy a křest’anského demokratického seskupení usilujícího o demokratizaci ČSL.

Osobnost Václava Ryneše charakterizovala nejen vědecká odpovědnost, ale především odpovědnost lidská, hluboká náboženská víra a národní cítění, kdy se nevzdával v období německé okupace a následné komunistické totality křest’anské humanity a mezilidské solidarity. Literární pozůstalost je uložena v archivu Národního muzea v Praze.

V Praze 3. ledna 2019

(Václav Ryneš) 